\section{Journal homepage:http://www.journalijar.com Journal DOI:10.21474/IJAR01}

\section{RESEARCH ARTICLE}

\section{INTERNATIONAL JOURNAL}

OF ADVANCED RESEARCH

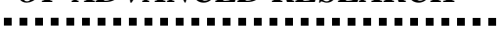

ISSN NO. 2320-5407

Esthetic Management Of Papillary Penetrating Frenum Using Conventional Technique: A Case Report with one year follow up.

${ }^{*}$ Dr. Noopur Kaushik ${ }^{1}$, Dr. Nikhil Srivastava ${ }^{2}$, Dr. Mayur Kaushik ${ }^{3}$, Dr. Neha Sharma ${ }^{4}$ and Dr. Sakshi Khattar ${ }^{5}$.

1. Reader, Department of Paedodontics and Preventive Dentistry, Subharti Dental College and Hospital, Swami VivekanandSubharti University, Subhartipuram, Delhi - Haridwar, Bypass Road, NH-58, Meerut-250005,

Uttar Pradesh, India.

2. Principal\& HOD, Department of Paedodontics and Preventive Dentistry, Subharti Dental College and Hospital, Swami VivekanandSubharti University, Subhartipuram, Delhi - Haridwar, Bypass Road, NH-58, Meerut250005, Uttar Pradesh, India.

3. Professor, Department Of Periodontology, Subharti Dental College and Hospital, Swami VivekanandSubharti University, Subhartipuram, Delhi - Haridwar, Bypass Road, NH-58, Meerut-250005,Uttar Pradesh, India.

4. Post graduate student, Department of Paedodontics and Preventive Dentistry, Subharti Dental College and Hospital, Swami VivekanandSubharti University, Subhartipuram, Delhi - Haridwar, Bypass Road, NH-58, Meerut-250005, Uttar Pradesh, India.

5. Post graduate student, Department Of Periodontology, Subharti Dental College and Hospital, Swami VivekanandSubharti University, Subhartipuram, Delhi - Haridwar, Bypass Road, NH-58, Meerut-250005, Uttar Pradesh, India.

\section{Manuscript Info}

Manuscript History:

Received: 12 May 2016

Final Accepted: 19 June 2016

Published Online: July 2016

Key words:

Frenum, Diastema, Scalpel,

Papillary penetrating, Esthetic

*Corresponding Author

\section{Abstract}

Afrenum is a mucous membrane fold that attaches the lipand the cheek to the alveolar mucosa, the gingiva, and theunderlying periosteum. It has no specific function. Sometimes, the maxillary frenum maypresent aesthetic problems or compromise the treatment outcome in the midline diastema cases, thus causing a recurrenceafter the treatment. An abnormal frenum is the source of concern for dentists and the management of such an aberrantfrenum is accomplished by performing a frenectomyi.e surgical excision of maxillary frenum. The present article mentions about the treatment of a papillary penetrating frenum using the conventional frenectomy technique with the one year follow up.

\title{
Noopur Kaushik.
}

Copy Right, IJAR, 2016,. All rights reserved.

\section{Introduction:-}

The maxillary anterior frenum is afold of mucous membrane that connectsthe midline of maxillary anteriorgingiva to the inner surface of the lip.(Gray $\mathbf{H ~ 1 9 9 5 ) . I t ~ i s ~ a ~ n o r m a l ~ a n a t o m i c a l ~ f i n d i n g ~ i n ~ t h e ~ o r a l ~ c a v i t y . ~ H o w e v e r , ~ i f ~ t h i s ~}$ frenum is present as thick, broad and fibrous tissue with papillary penetrating attachment, it may interfere with the normal function of the upper lip, the maintainence of proper oral hygiene and may lead to the compromised esthetics and diastema formation and gingival recession.(Devishree et al 2012)

Maxillary anterior spacing or diastema is a common aesthetic complaint of patients and is frequently seen in children especially in the mixed dentition stage. The maxillary midline diastema, locatedbetween the maxillary central incisors, isrelatively common during the mixed dentition stage. Though, a midline diastemawider than $2 \mathrm{~mm}$ rarely closes spontaneouslyduring further development, this persistentpresence has long been considereda pathologic entity and dental abnormality. Various factors can be contributing towards such pathological conditions.(Lindsey D1977 )

In rare cases, the maxillary frenum ifexceptionally hypertrophic, may inhibit theorthodontic closure and may become traumatizedand painful. In these cases, it isadvisable to surgically remove it before theend of the orthodontic therapy. (Meister F et al 1981)Furthermore, it has been shown that theremoval of the frenum before orthodontic 
leads to a more rapid crown approximationof the incisors.Abnormal frenal attachment can cause or aggravate the gingival recession. It may cause difficulty in the closure of the midline diastema.(Campbell PM et al1975 )

The indications for surgical removal ofthe maxillary midline frenum are usually thefollowing:

1. Prevention of median diastema formation

2. Prevention of postorthodontic relapse of a median diastema

3. Facilitation of oral hygiene procedures

4. Prevention of gingival recession (although maxillary frenum have never been clearly shown to lead to recession)(Kahnberg KE 1977)

The aberrant frena can be treated by frenectomyor by frenotomyprocedures. Frenectomyis the complete removal of the frenum, including its attachment to the underlying bone, while frenotomyis the incision and the relocation of the frenal attachment. (Dibart S et al2006 )

Various modalities can be used to surgically excise this aberrant frenum. It can be done by conventional method using blade and scalpel, using soft tissue laser or eletrocautery.

The techniques which were employed for conventional frenectomy were:

1. Conventional (Classical) frenectomy

2. Miller's technique

3. V-Y Plasty

4. Z Plasty

5. Frenectomy by ELECTROCAUTERY and LASER(Kumar V et al 2015 )

The present case report mentions about one such case where an aberrant frenum was excised surgically using the conventional (CLASSICAL) technique.

\section{Case report:-}

A 12-year-old patient reported to the Department ofPedodontics and Preventive Dentistry, Subharti Dental College and Hospital, Meerut with the chief complaintofsoft tissuegrowth in the upper front tooth region.(Fig 1-Fig 2) Also there was associated discomfort in speaking and chewing from front teeth. Patient's medical history did not reveal any systemic disease.Intra-oral examination revealed presence of a rotated right maxillary central incisorand a hypertrophied,broad, thick labial frenum of papillary penetrating typeattachment.

A diagnostic test, i.e., blanching test was performed foran abnormal high frenum attachment. After obtaining informed written consent from the parents, decision was made to remove high frenal attachment by a conventional surgical technique. The primary goal was to improve the esthetics and contours of superior lip line

Frenectomy was carried out under local anaesthesia using No. 11 Bard Parker blade. The frenum was engaged with a haemostat which was inserted into the depth of the vestibule and incisions were placed on the upper and the undersurface of the haemostat until the haemostat was free.(Fig 3) The triangular resected portion of the frenum with the haemostat was removed.( Fig 4- Fig 5) A blunt dissection was done on the bone to relieve the fibrous attachment.( Fig 6) The edges of the diamond shaped wound were sutured by using 5-0 black silk with interrupted sutures. (Fig 7) The area was covered with a periodontal pack. The pack and the sutures were removed 1 week postoperatively.

The patient was recalled after aweek for suture removal. After one week satisfactory healing was observed. The patient was followed up for a period of 1 year and Significant improvement was observed at the end of 1 year .Patient did not complain of any disturbance in speech and in chewing from front teeth after the removal of high frenum.

The overall appearanceof the patient's soft tissues, gingivaand superior lip were found tobe healthy and esthetic. The patient was referred to the department of orthodontics for the treatment of rotated maxillary central incisor. 


\section{Discussion:-}

Aesthetic concerns have led to an increasing importance in seeking dental treatment, with the purpose of achieving perfect smile. The continuing presence of a diastema between the maxillary central incisors, has often been considered as an aesthetic problem. The presence of an aberrant frenum being one of the aetiological factors for the persistence of a midline diastema, the focus on the frenum has become essential.(Huang WJ et al1995 )

Labial frenumoriginates as a remnant ofthe tectolabial bands, which are embryonicstructures and connect the tubercle of theupper lip to the palatine papilla.(Edwards JG 1977) Histologically, it contains elastic fibers andcollagen tissue components, although striated(skeletal) muscle fibers are frequentlyfound in biopsy specimens.(Ross RO et al 1990)

Frenal attachments have been classified asMucosal, Gingival, Papillary and Papilla penetrating.

1. Mucosal - when the frenal fibers are attached upto the mucogingival junction.

2. Gingival - when the fibers are inserted within theattached gingiva.

3. Papillary - when the fibers are extending into theinterdental papilla.

4. Papilla penetrating - when the frenal fibers crossthe alveolar process and extend up to the palatinepapilla.

The labial frenum is considered as pathological if it is abnormallylarge or wide and if no attached gingiva is apparent along themidline.The presence of abnormal frenumis theCause for midline diastema and was supported byother researches. (Angle EH 1907)

Midline diastema is often considered as the anterior midline spacing greater than $0.5 \mathrm{~mm}$ between the proximal surfaces of adjacent teeth.He reported that the incidences of maxillary and mandibularMidline diastema are $14.8 \%$ and $1.6 \%$, respectively .(Keene HJ 1963)

Weber listed the causes for spacing between the maxillary incisors as: a result of high frenum attachment; microdontia;macrognathia; supernumerary teeth; peg laterals; missing lateral incisors; midline cysts and habits such as thumb sucking, mouth-breathing and tongue-thrusting.(Weber1972)

Hence, frenectomy is an optimum solution to get rid of the abnormal frenum. Frenectomy can be done through conventional method using the blade and scalpel or using lasers and electrocautry. Though lasers and electrocautry has an added advantage of providing a bloodless field, the major advantage of doing frenectomy by conventional means is that the healing is by primary intention.

The classical technique was introduced by Archer (1961) and Kruger (1964). This approach was advocated in the midline diastema cases with an aberrant frenum to ensure the removal of the muscle fibres which were supposedly connecting the orbicularis oris with the palatine papilla (Jhaveri H 2006)

Generally abnormal frenal attachment may require removaleither before orthodontic treatment or at the end of activetreatment. The advantage of excision prior to orthodontictreatment is the ease of surgical access.(Koora et al 2007)

In the present case the rotated central incisor can be one of the cause of the high frenal attachment and the corresponding midline diastema. In some cases, the maxillary frenum ifexceptionally hypertrophic, inhibit theorthodontic closure or may become traumatized and painful. In these cases, it isadvised to surgically remove it before theend of the orthodontic therapy.

In the present case, a papillary penetrating frenum was observed in an adolescent. Considering the size and the type of attachment, surgical excision using the scalpel and blade was planned. The optimal dose of analgesics and antibiotics were prescribed to the patient to prevent post surgical complications.

Patient was recalled after one week for suture removal. Uneventful healing was observed during the healing phase. Patient was followed up for one year. There was no relapse of the outcome. (Fig 8 - Fig 9) 


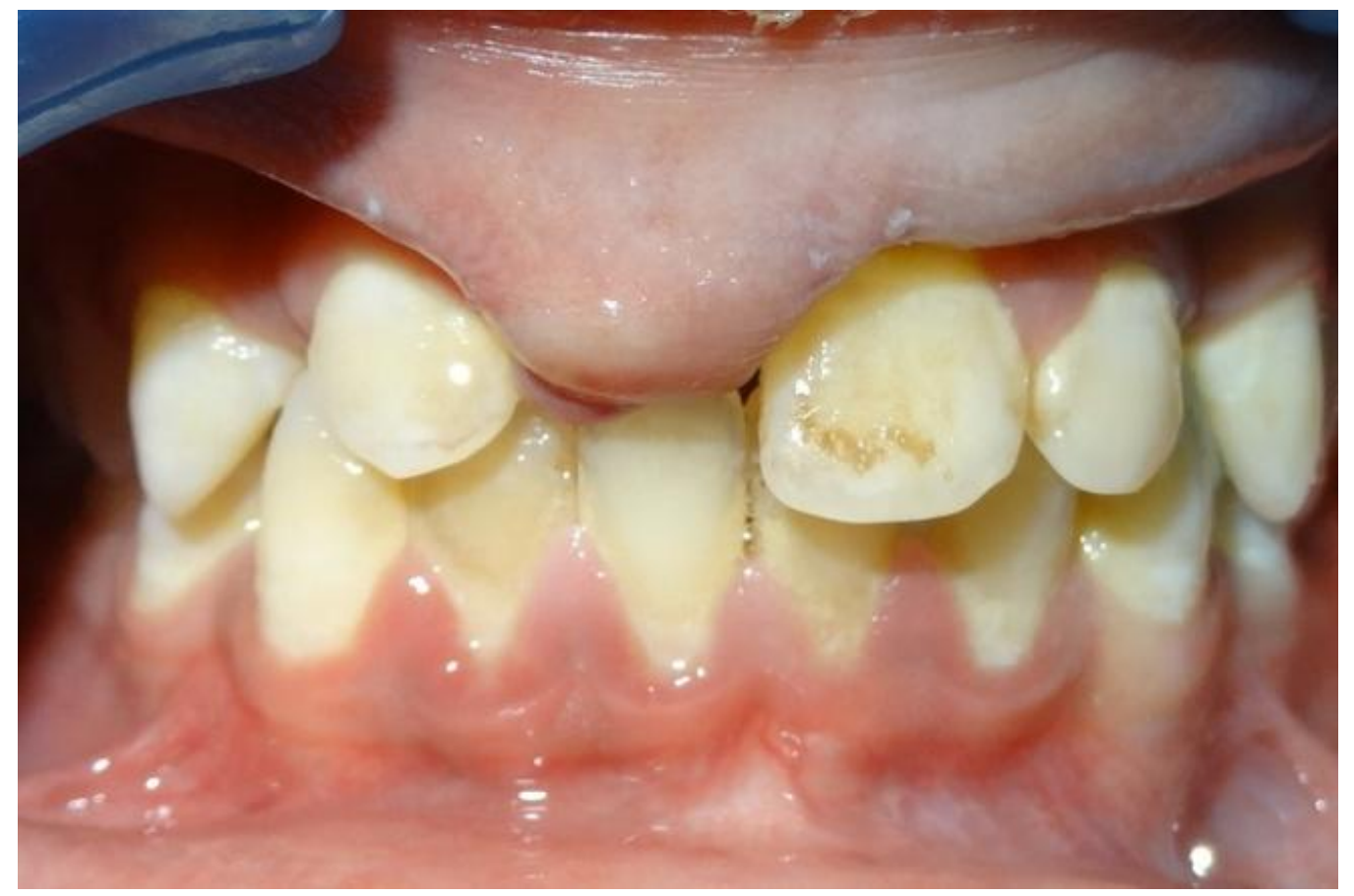

Fig 1: Pre -operative photograph showing papillary penetrating frenum attachment(BUCCAL ASPECT)

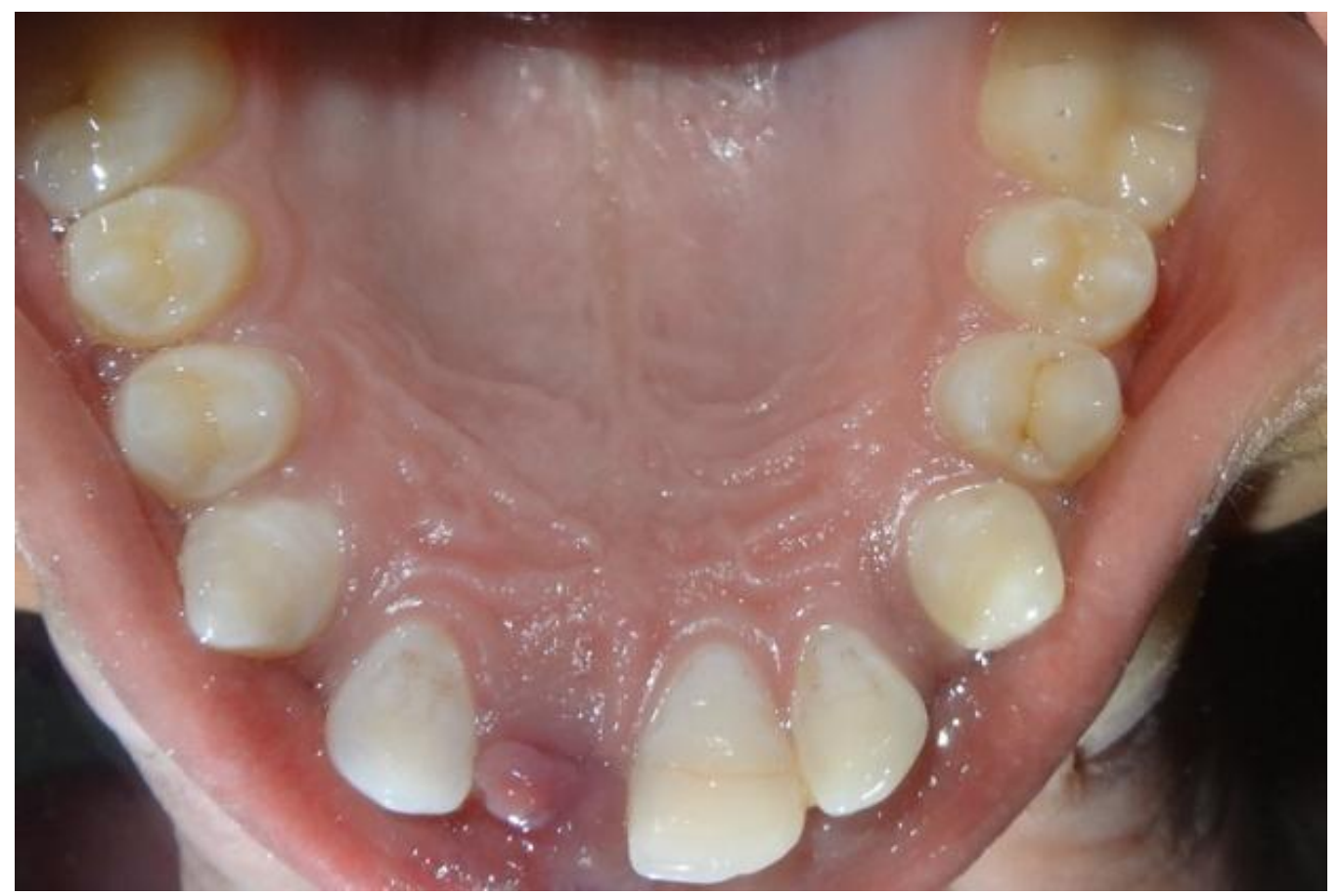

Fig 2: Pre -operative photograph showing papillary penetrating frenum attachment(PALATAL ASPECT) 


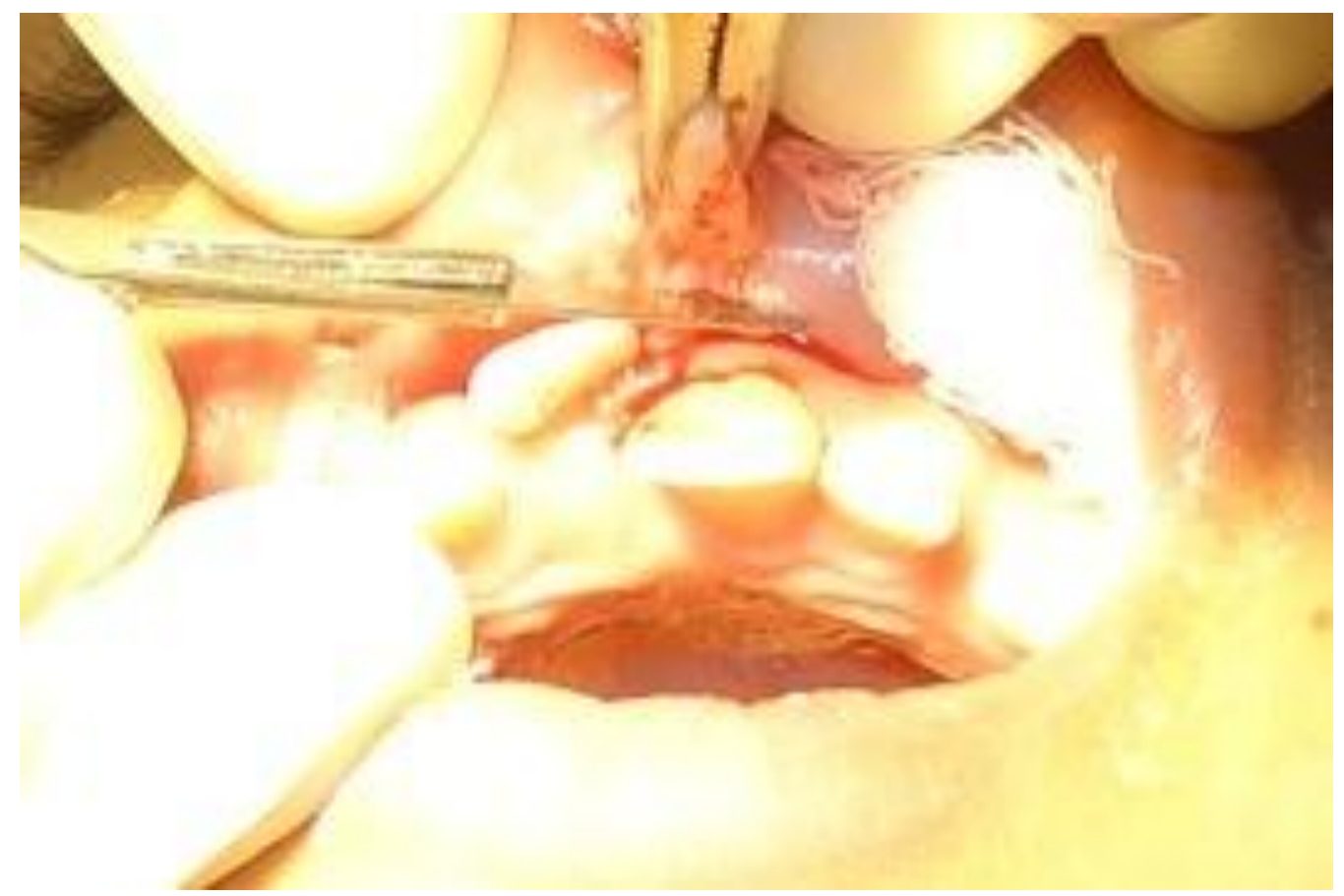

Fig 3: Intra-operative photograph showing incision.

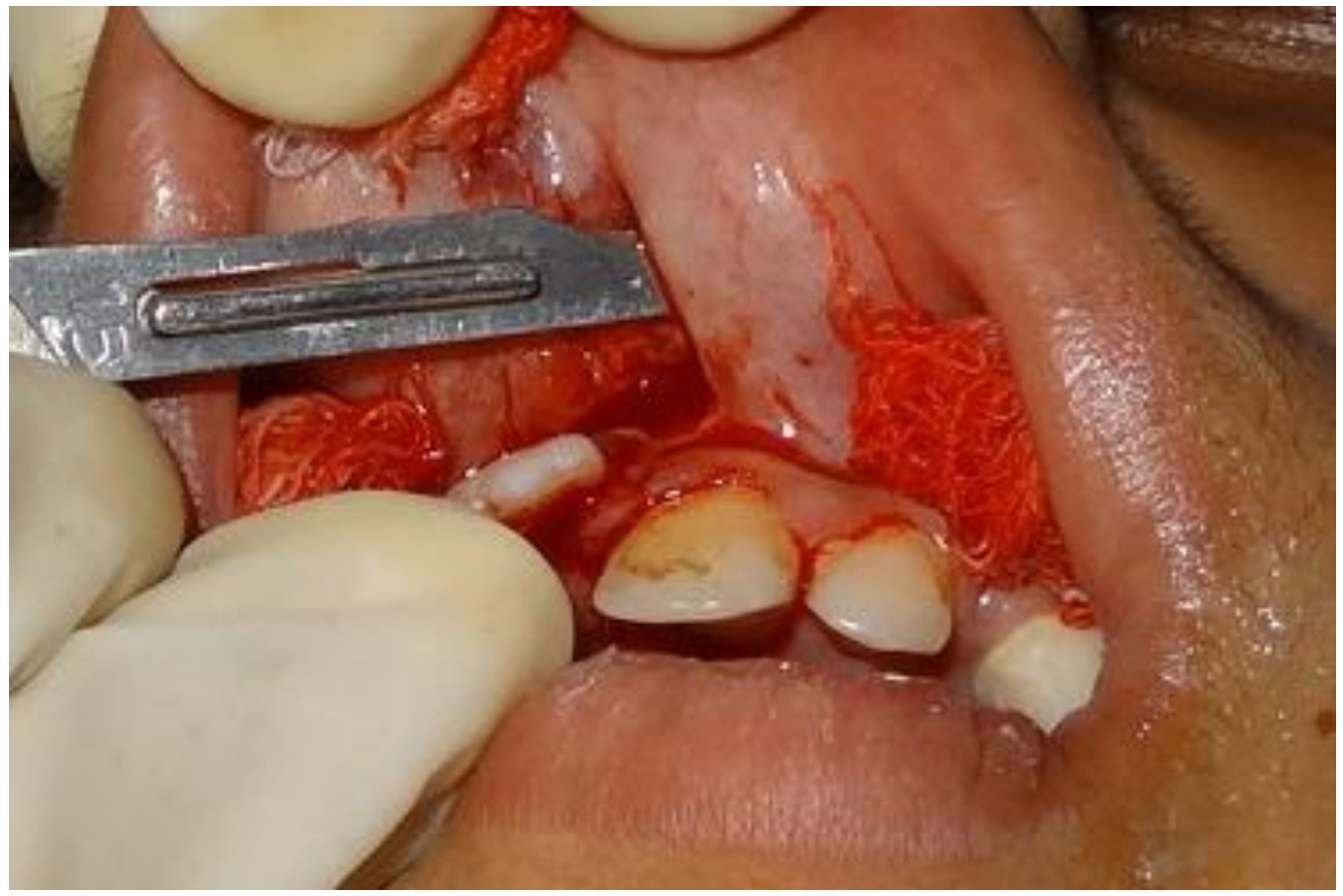

Fig 4: Intra-operative photograph showing undermining of fibers. 


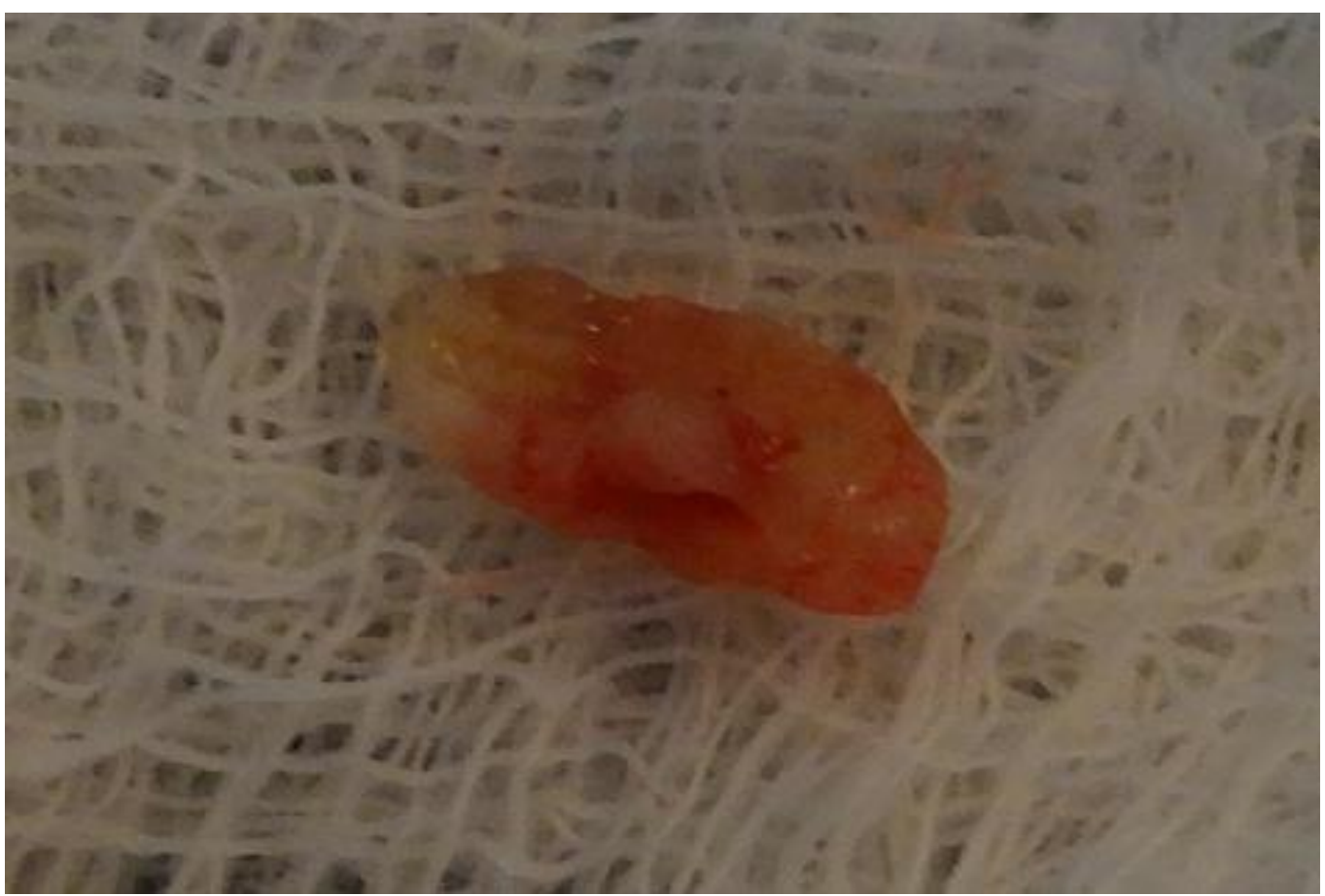

Fig 5: Complete removal of frenum

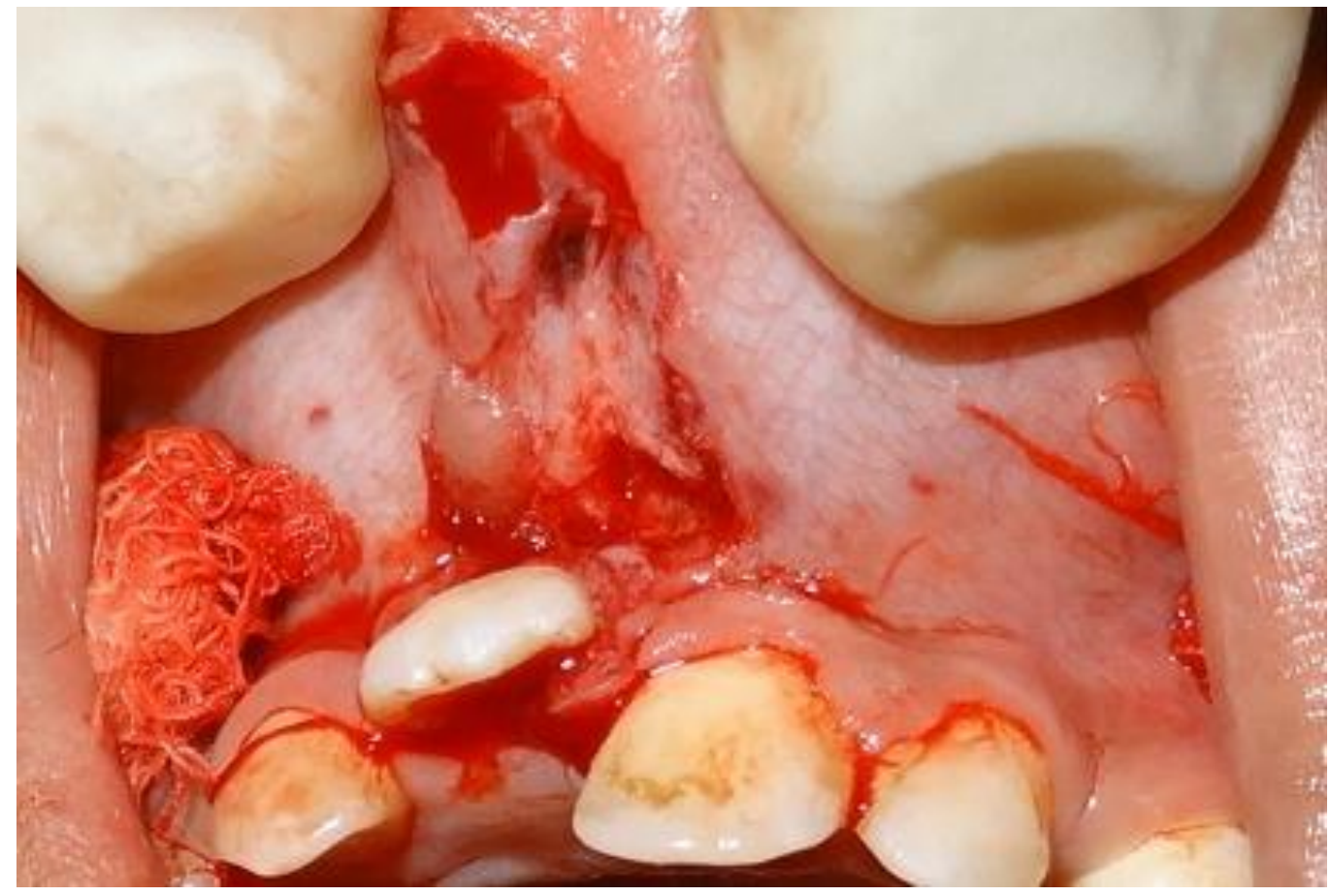

Fig 6: Tissue removed 


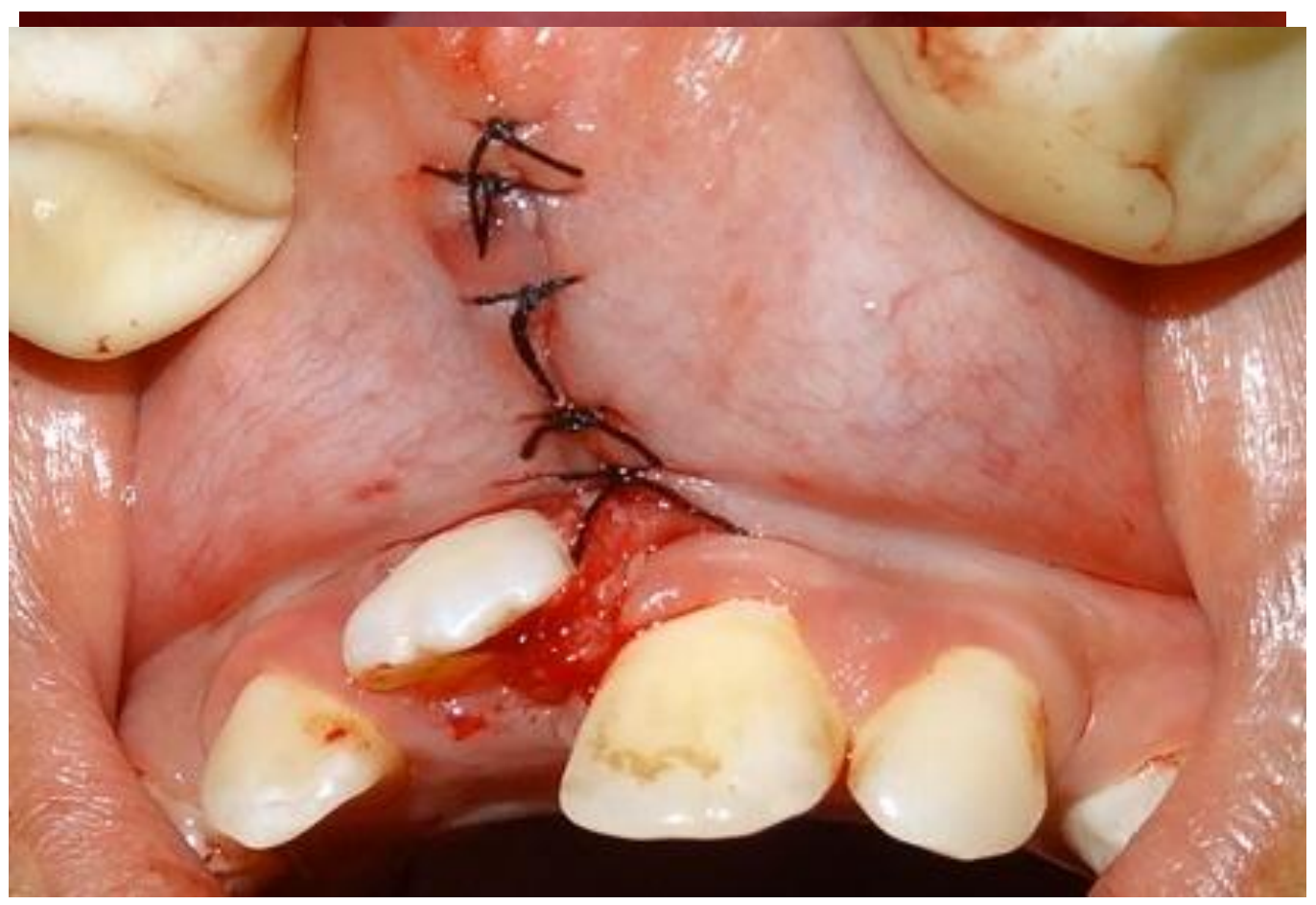

Fig 7: Sutures placed.

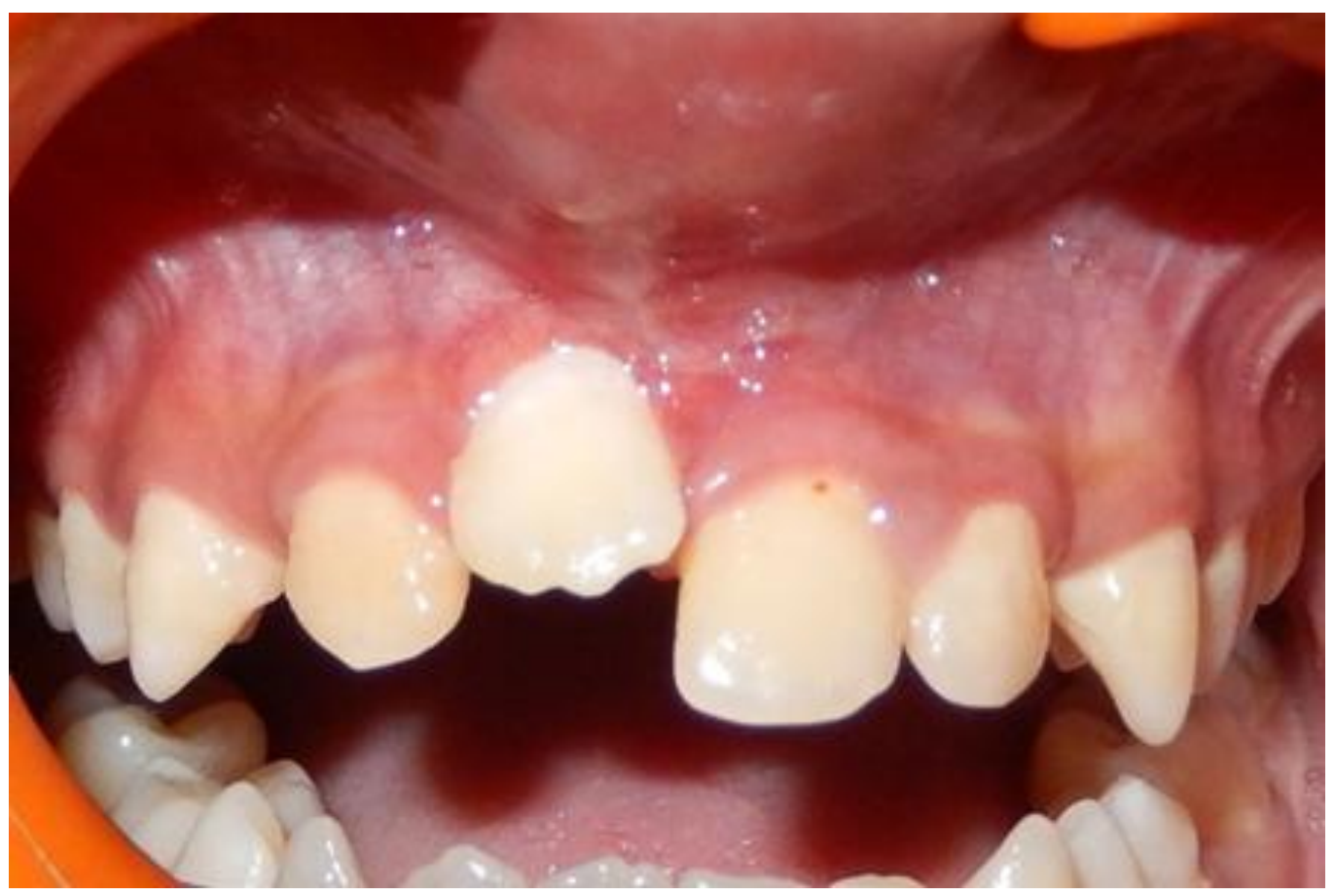

Fig 8: One week post- op photograph showing satisfactory healing. 


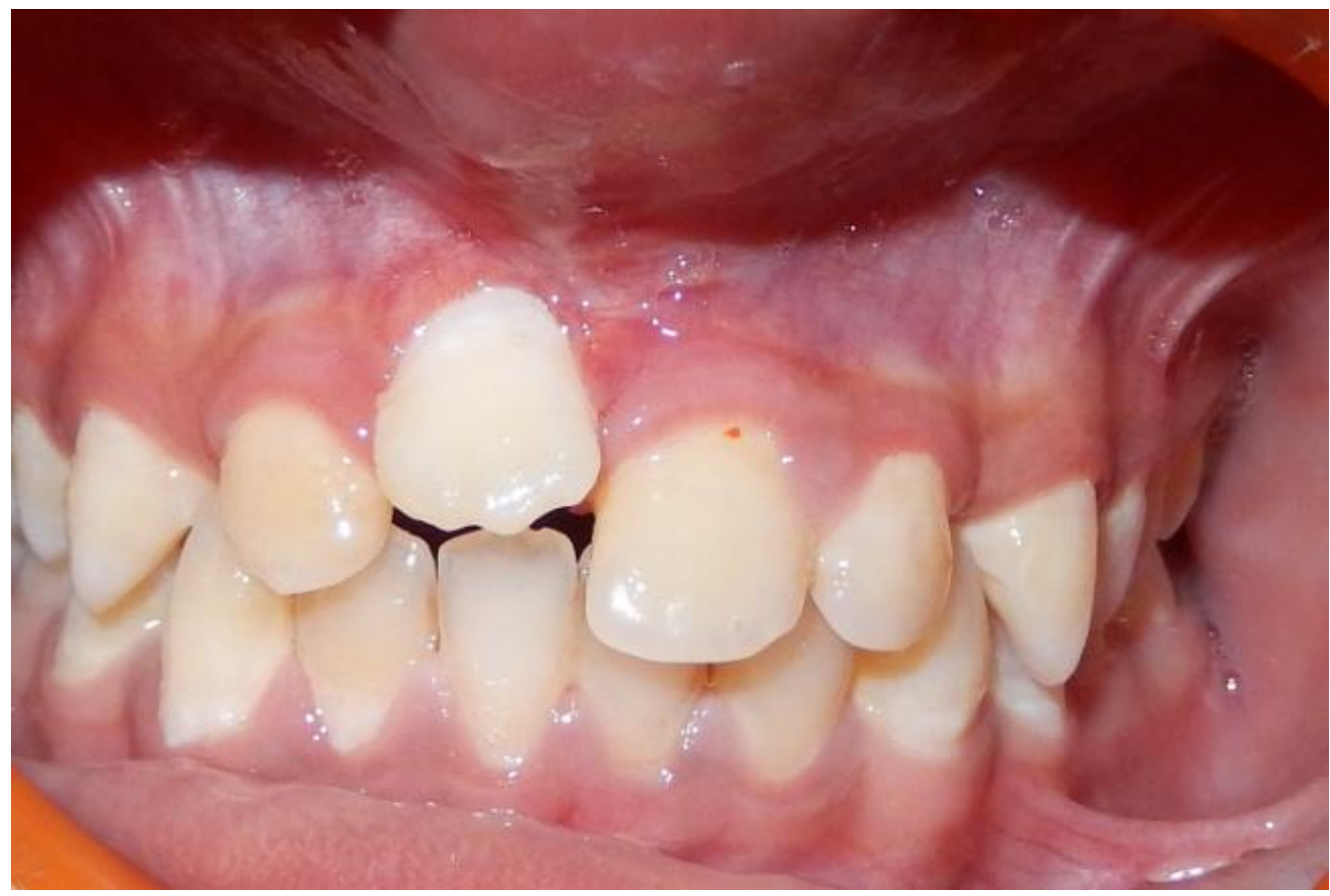

\section{Conclusion:-}

Fig 9: 1 year post op photograph showing no recurrence.

An aberrant frenum can be removed by any of the modification techniques that have been proposed, however, a functional and an aesthetic outcome can be achieved by a proper technique selection, based on the type of the frenal attachment. In the present case report, the hypertrophic frenum was present and successful outcome was achieved with the classical conventional technique. The technique was simple to perform and resulted in the desireable results with complete patient satisfaction.

\section{Bibliography:-}

1. Angle EH. Treatment of malocclusion of the teeth. 7th ed. S.S. White Dental Manufacturing Co: Philadelphia; 1907. p103-4.

2. Campbell PM, Moore JW, Matthews JL. Orthodontically corrected midline diastemas. A histologic study and surgical procedure. Am J Orthod 1975;67:139-158.

3. Devishree, Gujjari SK, Shubhashini P.V.Frenectomy: A Review with the Reports of Surgical Techniques. J ClinDiagn Res. 2012; 6: 1587-1592.

4. Dibart S, Karima M. Labial frenectomy alone or in combination with a free gingival autograft. In: Serge Dibart, MamdouKarima (eds) Practical Periodontal Plastic Surgery. Germany: Blackwell Munksgaard: 2006 ;p53.

5. Edwards JG. A clinical study: The diastema, the frenum, the frenectomy. Oral Health1977;67:51-62.

6. Gray H. Gray's Anatomy. 15th ed. New York, NY: Barnes and Noble Books; 1995:852.

7. Huang WJ, Creath CJ. The midline diastema: a review on its etiology and treatment. Pediatric Dentistry 1995;17:171-179.

8. Jhaveri H. The Aberrant Frenum. (ed), Dr. PD Miller the father of periodontal plastic surgery, 2006;29-34.

9. Kahnberg KE. Frenum surgery. A comparison of three surgical methods. Int J Oral Surg 1977;6:328-333.

10. Keene HJ. Distribution of diastemas in the dentition of man. Am J PhysAnthropol 1963;21:437-41.

11. Koora K, Muthu MS, Prabhu R. Spontaneous closure of midline diastema following frenectomy.J Indian SocPedodPrev 2007; 3: 23-26

12. Kumar V, Gulivindala D. Maxillary frenectomy with Hydrophotonics. Clinical Dentistry 2015; $3: 8-12$

13. Lindsey $\mathbf{D}$. The upper mid-line space and its relation to the labial fraenum in children and in adults. A statistical evaluation. Br Dent J 1977;143:327-332.

14. Meister F Jr, Van Swol RL, Rank DF. The maxillary anterior frenectomy. $J$ Wis Dent Assoc 1981;57:205-210.

15. Ross RO, Brown FM, Houston GD. Histological survey of the frena of the oral cavity. Quintessence Int 1990;21:233-237.

16. Weber. Quoted in: Orthodontic principles and practice. Graber TM. $3^{\text {rd }}$ ed. WB Saunders Co: 1972. 